\title{
COVID-19 in Ghana: An Overview of Government Contributions in Fighting this Pandemic
}

\author{
Yeboah Evans $^{\mathrm{a}, *}$ \& Rose Gyamea Kyeremeh ${ }^{\mathrm{b}}$ \\ ${ }^{a}$ Department of Economics and Management, Nanjing University of Science and Technology, 200 Xiaolingwei Street, Nanjing, 210094, China \\ ${ }^{b}$ Department of International Trade, Shenyang University of Chemical Technology, No-9. No.11 Street, Shenyang, 110142, China
}

\begin{abstract}
Coronavirus outbreak has brought significant negative impacts on developed and developing economies with Ghana, not an exemption. This pandemic has slow down economic activities across the globe through unplanned budget expenditures by various government. There is an increasing pressure on many governments to directed tremendous capital resource to stop the outbreak. The perspective of this paper is to provide, update, and inform concerning Covid-19 situation in Ghana, and also look at government expenditure on this pandemic and economic impact. This study employed the quantitative method which promotes the analysis of secondary sources of data. The study captured some of economic and livelihood programme implemented by the government of Ghana to support the most vulnerable persons. With Ghana currently having low active Covid-19 confirmed cases proves that the government has done well to control the spread of the virus.
\end{abstract}

Keywords: Ghana, Covid-19, Economic impact, Expenditure, FDI

\section{Introduction}

Coronavirus has brought many challenges in the global economy. Since the Covid-19 appearance in January 2020, the influence of the Covid-19 pandemic has significantly been observed throughout the length and breadth of countries and continent everywhere in the world (Lewis \& Richael, 2020). There has been a restriction on the free movement of people, goods and services, and cross-boarder-investment between countries. Major nations and enterprises are experiencing a diversity of challenges such as a decline in supply, raw material shortage and cancellation of export orders as a result of closing territorial borders. The massive depression of the 1930s and the vast latest of World Financial Crisis of 2007/2008 negatively impacted the global economy. However, as the activities unfold, it is becoming an increasing number of evidence that the Covid-19 pandemic and crippling economic outcomes would cease up in the annals of financial history as, perhaps, the singular match that decimated the global financial system in approaches never imagined (Ofori-Atta, 2020). Ghana has recorded many cases more than South Africa and Cameroon as a result of the mass testing capacity through the contact test-and trace model. The current forecast does no longer predict shrinkage for Ghana this fiscal year, the nation's forecasted real gross domestic product increase in 2020 used to be down drastically from a projection of 5.8percent to 1.5percent in the International Monetary Fund (IMF) current World Economic Outlook (IMF, 2020). It would be the country's minimum growth recorded since 198. However, it would nearly without a doubt entail a decline of per capita gross domestic product, thinking about that Ghana's 2.2percent gross domestic product(GDP) boom in 2015 pushed per capita rise beneath zero that year (World Bank Development Indicators Database, 2020; International Monetary Fund, 2020). The IMF report indicates that the Ghana government has committed an estimated amount of GHc11.2billion to the pandemic and its social and economic out-turn. The most significant share of these funds (GHc10.6 billion) is being used under the Covid-19 Alleviation Programme to aid selected industries (for instance pharmaceutical sector

\footnotetext{
* Corresponding author.

E-mail address: yeboahevans56@yahoo.com (Yeboah Evans)
} 
producing and supplying coronavirus drugs and equipment). Helping SMEs, finance guarantees and first-loss instrument, build or upgrade 100 district and regional hospitals and address availability of test kits, pharmaceuticals, equipment, and bed capacity. As the pandemic increases the country's expenditure, this paper seeks to target government spending in fighting this Coronavirus.

\subsection{Background of Covid-19 situation in Ghana}

Ghana recorded the first confirmed coronavirus case on March 12, 2020. Beginning March 16, the Ghana government implanted sweeping social distancing initiatives and travel restrictions to prevent an outbreak, for instance:

a. Suspension of all public meetings exceeding 25 people for one month;

b. Closure of all universities and schools until further notice; and

c. Mandatory 14-day self-quarantine for any Ghanaian resident who has been to a nation with at least 200 confirmed cases of Covid-19, with the last 14 days. However, the measures implanted by the government on the earlier stage did not effectively as the virus continue to spread among people. On March 23, the country closed all its borders to travelers, and March 30, 2020, there was a partial lockdown of major urban areas such as Accra and Kumasi was implemented. As of October 7, 2020. From the first registered confirmed Coronavirus case in March, the country has recorded 30,366 cases, with 26,687 recoveries and 153 deaths as of July 20, 2020, and the death rate of $0.50 \%$ was among the lowest in the world. Ghana has confirmed 46,829 Covid-19 cases with 46,060 recoveries/discharge and 303death. There are 466 active cases. The gender distribution of the confirmed cases is $58 \%$ of male and $42 \%$ of female. Table 1 below the breakdown of cases among regions.

Table 1. Cumulative Cases Per Region (Cases Count from Highest to Lowest)

\begin{tabular}{cc}
\hline Region & Number of Confirmed Cases \\
\hline Greater Accra & 24,094 \\
Ashanti & 10,977 \\
Western & 2,969 \\
Eastern & 2,412 \\
Central & 1,928 \\
Bono East & 781 \\
Volta & 672 \\
Western North & 638 \\
Northern & 547 \\
Ahafo & 527 \\
Bono & 511 \\
Upper East & 315 \\
Oti & 242 \\
Upper West & 90 \\
Savannah & 62 \\
North East & 19 \\
\hline
\end{tabular}

Source: Ghanahealthservice

According to the Ghana Health Service as part of the country's emergency preparedness and response to control the spread of Covid-19 brought-out the following measures outlined as fellows:

- Regular washing of hands with soap under running water

- The use of alcohol hand rub where available

- Keeping a distance of at least one step (one meter) from a person showing signs of fever, cough and difficulty in breathing

- When contact with a sick person or with potentially infected surfaces or objects occurs, to avoid touching the eyes, nose or mouth with unwashed hands

- Advising people to be physically active, drinking plenty of water, eating well, reduce stress and have enough sleep 
- People should seek treatment immediately if an infection is suspected if symptoms occur or the advised by a health worker

- Report any symptoms to the nearest health facility

- Use of tissue paper or handkerchief when coughing

\section{Economic impact}

Ghana was capture among the fastest growing economies in Africa. However, as Ghana's economy was starting to recover from crisis and to consolidate recent benefit for growth and jobs, the Coronavirus outbreak affected the country leading to the strict movement restrictions. The sectors greatly affected include hotel and hospitality industry, foreign direct investment, trade and industry, agriculture, health, transportation, manufacturing, real estates, finance and education. The socio-economic effect of Covid-19 on the Ghanaian economy can be of direct and indirect ways. The Coronavirus has a direct impact on production, trade and investment activities within Ghana and between Ghana and other parts of the world (specifically China, Europe, India and the United States), on worldwide commodity (crude oil, gold, and cocoa) prices, on tourist flows, on fiscal stance, and on human life, especially the health and vitality of the most vulnerable; and indirectly through the decreasing of global economic development, supply chain disruptions, and by extension, the adverse effect on Ghana's growth (Ken, 2020). The significant primary outcomes of the Covid-19 on Ghana's economy are as follows;

\subsection{Impact on the Hospitality Industry}

The global trend of airline companies temporary seizing operation and cancellation of flights, closure of borders (land, air and sea), the need to observe social distancing, including a ban on social gatherings, are having significant adverse effects on economic activities in the industry. The occupancy rate of the hotel is down from 70 percent to under $30 \%$, and staff been laid-off. Before the impact of the lockdown, restaurants were experiencing an average decrease in the patronage of 60 percent. The scheduled international conferences and events in Ghana were cancelled, including the $4^{\text {th }}$ African Union Specialized Technical Committee(STC) on Finance, Monetary Affairs, Economic Planning and Integration meeting and the G24 Technical meetings, which were programmed in March 2020, brought a loss of thousand combined participants and therefore a loss in 1000 hotel beds (Ken, 2020).

\subsection{Impact on Investments}

The flow of foreign direct investment (FDI) around the world in 2020 have slowed down as a result of uncertainties surrounding the effect of Covid-19. The Coronavirus crisis has caused a dramatic decline in FDI. According to UNCTAD world investment report 2020, global FDI flows are forecast to reduce by up to $40 \%$ in 2020 , from their 2019 value of $\$ 1.54$ trillion. This would bring FDI beneath $\$ 1$ trillion for the first time since 2005 . FDI is projected to slump by a further 5 to 10 percent in 2021 and to initiate a recovery in 2022 (UNCTAD, 2020). Foreign investors are not able to arrive into Ghana to transact or undertake feasibility studies due to the closure of most borders of nations including Ghana's and, in many cases, restrictions imposed in their own countries of origin (Ken, 2020).

\subsection{Impact on Budget}

Regarding the 2020 budget execution diverging extensive from it projected path amid high uncertainty, budgeting all through the crisis has come to a non-stop reactive process, putting lines on ministries of finance(MOFs) (Teresa, Laura, Bruno, Fazeer, Vicent, \& Claude, 2020). The Covid-19 pandemic has brought shortfall in revenue mobilization governments. Ghana's 2020 budget has been erupted by the Coronavirus. The fiscal impact analysis of the Covid-19 by the Ministry of Finance(MoF) indicated to be in the following areas, significant shortfalls in petroleum receipt, reduction in import duties, a shortfall in other tax revenue, increased health-related expenditures, and tight financing conditions. The government of Ghana projected a crude oil price of 62.60 per barrel in the 2020 budget, following PRMA (Act 815). The international price of crude oil has decreased massively since the 
Coronavirus outbreak. Preliminary analysis indicates that at an average crude oil price of US $\$ 30$ per barrel for 2020 , the government witness a shortfall in crude oil revenue amounting to GHc 5,679 million (Ken, 2020). The corresponding forecasted loss in annual budget funding amount is GHc 3,526 million, shortfall of GHc 1,058 million in the Ghana stabilization fund, GHc 453 million loss in Ghana heritage fund, and GHc 642 million in Ghana national petroleum corporation.

In the aspect of the shortfall in tax revenues mobilization by the government, will result in the anticipated reduction in import volumes and values, as well as a slowdown in economic activities. This will affect both import duties and other tax receipts. The short-term analysis shows a total estimated of GHc 2,254 million shortfalls in the non-oil tax revenue. The import duties will fall short of the target by GHc 808 million for 2020 fiscal year and projected slowdown in non-oil GDP as a result of the Covid-19 pandemic is forecasted to experience shortfalls in tax revenues (excluding oil tax revenue and import duties) amount of GHc1,446 million.

The cost of the national preparedness and response plan is prepared by the ministry of health and the World Bank. This preparedness plan seeks to, among others, help early detection and effectively manage and control a Coronavirus outbreak in Ghana. However, the initial cost of the programme and activities under Covid-19 preparedness and response plan was estimated to be GHc 572 million (US\$100 million) (Ken, 2020).

\subsection{Impact on Education}

The coronavirus pandemic has brought about changes in most countries academic calendars. Many schools across the globe were closed down as a result of lockdown effects from the Covid-19. According to UNESCO estimates as of May 6, 2020, 177 nations have closed schools nationwide, affecting over 1.2billion learners worldwide, who are mainly children and youth. School closures in the aspect of Covid-19 have been essential worldwide to slow the spread of the disease and mitigate the impacts on the health system (Unesco \& Unicef, 2020). The coronavirus pandemic has changed the lives of many students, teachers, and parents across the globe with millions of teaching and learning from home. March 15, 2020, the President of Ghana instructed the closure of all educational institutions in the country, impacting some 9.2million primary school students (kindergarten, primary and junior high schools) and 0.5 million tertiary education student. The Ministry of Education(MoE) and the Ghana Education Service(GES) provided temporary measures aimed at making sure opportunities for continuous learning even with education institutions closed. After education institutions closures were announced, MoE and GES announced the Coronavirus emergency support provision of distance and remote learning systems solution, which was followed by the launch of distance and online learning platforms and the rolling out of lessons show on Ghana Learning television(GLTV) for one million senior high school students (Unesco \& Unicef, 2020). Digital content made for 8.2 million kindergartens through junior high school students for television, radio and online learning is launching from the third term. Despite the measures taken by the Ministry of Education and the Ghana Education Service, there were still many challenges faced by some students. Looking at the standard of living of many people in Ghana, not all the students have access to $\mathrm{TV}$, radio, and internet. According to UNICEF's U-report polls around the 16 regions suggest good progress with 36percent respondents showing their availability to access learning when given the opportunity, and $42 \%, 24 \%$ and $20 \%$ showed interest for learning through the internet, short message service(SMS) and television programme (UNICEF, 2020).

\section{Works related to Covid-19 in Ghana}

There has been much research work done by numerous scholars since the outbreak of the Covid-19. However, there are limited papers concerning Ghana as the primary target. (Lewis \& Richael, 2020), exploring Ghana's preventive measures for controlling the spread of Covid-19 pandemic among its population and social-economic effect of these measures in urban marketplaces. It was proposed that Ghana's Covid-19 method in marketplaces was characterized by improving hygiene conditions through disinfection of all markets, closing down markets to support social distancing among traders, and imposing a lockdown to decongest densely populated marketplaces. The authors argued that the socio-economic effect of the Covid-19 pandemic in marketplaces was evident in the rise of food 
prices, the economic hardships associated with the lockdown directive, and the forceful relocation and decongestion excises to regulate social distancing among traders.

(Randy \& Isaac, 2020), the intention to update on the incidence and inform concerning the Covid-19 in Ghana, also target the economic impact on the world pandemic on a developing nation like from the international trade perspective. The authors concluded that Covid-19 has had and continues to a have colossal impact on Ghana both positively and negatively. Upon a careful assessment, it is without a doubt that the adverse implications seem to outweigh the positive.

(Joshua-Luther \& Cornelius, 2020), examining the impact of Covid-19 on education in Ghana. The following objectives guide; to evaluate the awareness of Coronavirus among student in Ghana, to investigate the effect of Covid-19 on education in Ghana and to assess the post effect of Covid-19 pandemic on the educational system in Ghana. The study used the descriptive and explanatory design; the authors employed questionnaires in addition to the library to collect data. The study outcome showed that Covid-19 pandemic has a significant effect on education in Ghana; based on the results from the study, schools want resources to reconstruct the loss in education through the epidemic.

(Laud, 2020), a study which briefly discusses Ghana's Preparedness, and aspect of its demography and underlying disease condition/burden and how it could pan out the Coronavirus outbreak; Ghana reported its first case on March 12, 2020. The authors concluded that the emergence of the virus in Ghana had exposed severe shortfalls and inadequacies in purported preparedness; perhaps the country's much-communicated preparation was more rhetorical than practical.

(Harriet, Adolphina, Justice, John, Bismark, \& Richmond, 2020) conducting an exploratory observational study to assess compliance with the recommendation in selected transportation stations in the Greater Accra region. The audit of the transport station showed that compliance with Coronavirus prevention measures in public transportation stations in the Greater Accra region remained a challenge.

\section{Data and Methodology}

Data for this paper has been collected through secondary sources for writing this paper. Most of the information has been gathered from the Ministry of Finance, Bank of Ghana, and Ghana Health Service. Observing the trend of government contribution in fighting this Covid-19 pandemic and its impacts on the Ghanaian economy. As the number of Covid-19 confirmed cases and active cases keep changing daily. Concerning this study, there is meaningful data available for the set target to be achieved. In this case, to execute the target outlined in this paper, a quantitative method is considered. The intention of taking into account this procedure is to inform and provide updates on Covid-19 situation in Ghana and the government economic and livelihood programme to support the most venerable.

\section{Government Expenditure on Covid-19}

The government of Ghana had spent an amount of GHc1,937 million on direct Covid-19-related expenditure as at the End-June 2020. An amount of GHc1,609 million of the total amount spent was sourced from the Contingency Fund and other government of Ghana(GoG) sources, including the International Monetary Fund facility, to support households and businesses and provide relief for water and electricity payment, among others. The World Banksupported Ghana with GHc328 million for the implementation of Covid-19 Preparedness Plan activities submitted by the Ministry of Health. Table 2 below shows a detailed breakdown of expenditures. 
Table 2. Status of Covid-19 Expenditure as at End-June 2020

\begin{tabular}{|c|c|c|c|c|}
\hline Source & Funding & $\begin{array}{l}\text { Allocation(GHc } \\
\text { million) }\end{array}$ & $\begin{array}{l}\text { Payments(GHc } \\
\text { million) }\end{array}$ & $\begin{array}{l}\text { Balance(GHc } \\
\text { million) }\end{array}$ \\
\hline \multirow[t]{17}{*}{ GOG } & CAP Contingency & 1,204 & 621 & 582 \\
\hline & Fund & & & \\
\hline & Allocation from the & & & \\
\hline & Budget to Support & 100 & 23 & 77 \\
\hline & COVID-19 & & & \\
\hline & Measures & & & \\
\hline & Government & 1,020 & 693 & 328 \\
\hline & Electricity Relief & & & \\
\hline & Allocation from & & & \\
\hline & Budget to support & 122 & 122 & 0 \\
\hline & $\begin{array}{l}\text { Fumigation and } \\
\text { management of }\end{array}$ & & & \\
\hline & landfill sites & & & \\
\hline & Allocation from & & & \\
\hline & Budget for & & & \\
\hline & Procurement of & 150 & 150 & 0 \\
\hline & $\begin{array}{l}\text { Fumigation towards } \\
\text { reopening of school }\end{array}$ & & & \\
\hline & Sub-Total & 2,596 & 1,610 & 986 \\
\hline \multirow[t]{5}{*}{ World Bank } & GARID CERC & 362 & 232 & 130 \\
\hline & Fast track Covid-19 & 195 & 96 & 99 \\
\hline & Facility & & & \\
\hline & Sub-Total & 557 & 328 & 229 \\
\hline & Grand Total & 3,153 & 1,938 & 1,215 \\
\hline
\end{tabular}

Source: Ministry of Finance (MoF)

The government of Ghana entirely covered the consumption expenses of one million lifeline customers and 50\% subsidies for the consumption of all other users. The livelihood preservation programme for the 4,086,286 households and 686,522 businesses was an unplanned expenditure. However, the Community Water and Sanitation Agency provided 174 piped-water system to serve 268,861 people between April and June 2020. As part of the relief program, a total of $1,755,907.82$ cubic meters of water was provided by the Community Water and Sanitation Agency at no cost to beneficiaries. The total expenditure of the Water Relief Programme to government is estimated at GHc275.5 million, of which GH199.3 was paid by the end of June 2020. During the lockdown in the two major cities (Accra and Kumasi), government through the Gender Ministry and the National Disaster Management Organization (NADMO) supplied 1,827,581 and 917,142 cooked foods packs to vulnerable people within these metropolitan areas. In terms of the provision of dry food pack and hot cooked meals cost government GH54.3 million, and the government transferred an amount of GHc50.2 million the 400,00 most-vulnerable persons under the Livelihood Empowerment Against Poverty (LEAP) Programme.

\subsection{Bank of Ghana(BoG) Policy Responses to Covid-19}

As part of ensuring smooth banking activities during this Covid-19 pandemic, the government through the Bank of Ghana reacted to the Coronavirus-related issues in the banking sector with a suite of policy measures design to support businesses and the economy as a whole. The measures include:

- lowering the monetary policy rate 150 basis point to $14.5 \%$; 
- reducing the Primary Reserve Requirement from $10 \%$ to $8 \%$ to provide more liquidity to banks to support critical sectors of the economy;

- reducing the Capital Adequacy Requirement from $13 \%$ to $11.5 \%$;

- providing a syndication facility of GH3.0 billion to support industry, especially in the pharmaceutical, hospitality, service and manufacturing sectors;

- grating 6month moratorium of principal repayment for selected sectors businesses; and

- reducing interest rates based on the Ghana Reference Rate(GRR) by 200 base points ( $2 \%$ per annum).

These measures implemented by the Bank of Ghana enabled the financial sector to provide an estimated amount of GHc7 billion worth of support to borrowers (between March and June 2020).

\subsection{Tax relief for Households and Businesses}

For the government to reduce pressure on revenue as a result of the Covid-19 pandemic, over the past few months, the government has implemented numerous measures to support businesses and persons against any economic difficulties brought by the pandemic. These include:

- extension of due dates for filing of Income Tax returns from 4 to 6 months after the end of the basis year;

- remission of penalties on principal debts to taxpayers who redeemed, their outstanding debts due to GRA up to $30^{\text {th }}$ June 2020;

- permit the deduction of contribution and donation toward Covid-19 as allowable expenses for income tax purposes;

- waiver of Value Added Tax, National Health Insurance Levy and GETFund Levy on donations of stock of equipment and goods for fighting the Covid-19;

- $\quad$ waiver of income taxes on Third-Tier pension withdrawals;

- waiver of income tax on personal emoluments of all health workers for the period of April 2020 to September 2020; and

- waiver of income tax on 50\% additional allowances paid to staff of frontline health facilities for the period March 2020 to September 2020.

\section{Conclusion}

Coronavirus, as a worldwide pandemic, has brought challenges in the Ghanaian economy. Despite of government implementation of sound measures to mitigate the spread of the virus was not effective in the short-term but much effective and efficient in the long-term. With the negative impacts of Covid-19 on the global economy has directly affected economic activities in Ghana. Covid-19 has had both positive and negative impact on Ghana's economy. The substantial spending on managing and controlling the spread of the virus by the government of Ghana has been very significant. The relief programme initiated by the government during this pandemic has helped save many lives compared to some countries in Europe and the United States. However, this may not be sufficient to capture all other expenditures incurred by the government in all the sectors of the economy.

\section{References}

Harriet, A. B., Adolphina, A.-L., Justice, M. A., John, K. G., Bismark, S., \& Richmond, A. (2020). Limiting spread of COVID-19 in Ghana: Compliance audit of selected transportation stations in the Greater Accra region of Ghana. Plos One, 15 (1).

IMF. (2020). World Economic Outlook: The Great Lockdown. Washington DC: International Monetary Fund.

IMF, (2020). Policy Responses to COVID-19. https://www.imf.org/en/topics/imf-and-covid19/Policy-Responses-toCOVID-19 
Joshua-Luther, N. U., \& Cornelius, B. U. (2020). The Impact of COVID-19 on Education in Ghana. Asian Journal of Education and Social Studies , 9 (1), 23-33.

Ken, O.-A. (2020). Economic Impact of the COVID-19 Pandemic on the Economy of Ghana. Accra: Ministry of Finance.

Laud, K. A. (2020, March 27). Of the Covid-19 in Ghana - Preparedness, Demographics and Comorbidity. ResearchGate .

Lewis, A. A., \& Richael, O. M. (2020). Exploring the Socio-Economic Impact of COVID-19 Pandemic in Marketplaces in Urban Ghana. Africa Spectrum, 00 (0), 1-12.

Randy, A., \& Isaac, A. F. (2020). Ghana in the Face of COVID-19: Economic Impact of Coronavirus (2019-NCOV) Outbreak on Ghana. Open Journal of Business and Management , 8, 1404-1411.

Teresa, C., Laura, D., Bruno, I., Fazeer, S. R., Vicent, T., \& Claude, W. (2020, June). Budgeting in a Crisis: Guidance for Preparing the 2021 Budget. International Monetory Fund .

UNCTAD. (2020). World Investment Report;International Production Beyond the Pandemic. Geneva: United Nations Conference on Trade and Development.

Unesco, \& Unicef. (2020). COVID-19:Socio-Economic Impact in Ghana. United Nations.

UNICEF. (2020). Ghana:COVID-19 Situtation Report-\#3. Accra: United Nations International Children's Emergency Fund. 